\title{
Overview of Class Actions: Italian Consumer Law and Cross-Border Litigation
}

\author{
By Maria Luisa Chiarella*
}

\begin{abstract}
Consumers and users are daily involved in commercial practices and transactions that can end up not pacifically. We buy items and services, we travel, we use public services and vehicles and we enter into contracts with banks, insurance and financial services companies. The disputes arising from these everyday life events need collective remedies which may facilitates access to justice by those whose rights have been violated by one and the same professional. A class action allows a number of consumers to bring a case together before the Court to obtain compensation for a damage caused by the same professional. It is a lawsuit brought by a group of claimants, which allows them to enforce their rights collectively where they would not have done on an individual basis because of the cost, the risks and the time that legal proceedings entail. This paper analyses the peculiarities of this kind of litigation, in general and on a European perspective; then it tackles: the archetype of U.S., Italian class actions rules and cross-border litigations issues.
\end{abstract}

Keywords: Class actions; Consumer law; Access to justice; Legal certainty; Deterrence; Compensation; Private enforcement; Cross-border litigation.

\section{Introduction}

Consumers and users are daily involved in commercial practices and transactions that can potentially end up not pacifically. We buy items and services, we travel, we use public services and vehicles and we enter into contracts with banks, insurance and financial services companies.

Furthermore, since the use of standard contract terms is frequent, many consumers enter into the same contract and an unfair contract term can affect a vast number of consumers. In such cases where a conflict arises, the exercise of individual actions for damage compensation is vain since individual action means that costs, time, difficulty of access, the complexity of the dispute and the uncertainty of its outcome (i.e. the "risks" of the action) weighs on the consumer".

The multiplication and the fragmentation of the prejudices caused in the market society (for instance in the supply of mass goods or services), on the one hand, and the inadequacy of the remedy offered by the individual compensatory action, on the other, determine an unsatisfactory result.

The right formally recognised to the consumer to obtain the restoration of the suffered damages (on a case by case basis) remains substantially unrealised

\footnotetext{
*PhD, Senior Lecturer, Jean Monnet Teaching Staff, Magna Graecia University (Catanzaro-Italy). E-mail: mlchiarella@unicz.it. I want to thank Prof. Rosa Alcaro for the linguistic revision of this paper.

${ }^{1}$ In this sense, among others, Hodges (2010) at 370 et seq.; Benatti (2012) at 5 et seq.
} 
in the overwhelming majority of cases; moreover, the enterprise can enjoy the inefficiencies of the judiciary and trial system because, by subtracting a full and effective compensation or restitution obligation, it can preserve in full, or in any case to a very large extent, what we could define "over-profit" deriving from the unlawful behaviour ${ }^{2}$.

For this reason, class actions have been recognised in recent law reforms to pursue damage compensation, legal certainty (and - of course - less overloading of Courts), private enforcement and deterrence towards future unlawful behaviour ${ }^{3}$. Obtaining compensation for the harm suffered by individuals is the «raison d'être» of class actions ${ }^{4}$.

Market regulation aims to maximise social welfare by guiding a proper behaviour of social agents, but however it may not be able to answer adequately to market failure: for example, the fact that a number of economic agents can't protect their own rights against injures. This fact may produce a severe effect of under-deterrence in market ${ }^{5}$.

In this context, class actions are useful to solve problems relating to the access of consumers to justice, with reference both to the simplification of ordinary civil proceedings, aimed at resolving conflicts of modest economic value (so-called small claims) and to the promotion and enhancement of out-ofcourt dispute resolution tools (so-called alternative dispute resolution) thorough actions of collective interest ${ }^{6}$.

A dispute arising from consumers everyday life need collective remedies which may facilitate access to justice by those whose rights have been violated by one and the same entity (the so-called "mass torts") ${ }^{7}$. A class action, i.e. a lawsuit brought by a group of claimants, allows claimants to enforce their rights collectively where they would not have done on an individual basis because of the cost or the time that it entails ${ }^{8}$.

The Class Action (art. 140-bis, Italian Consumer Code: see infra par. 4) is an action aimed to "protect the homogeneous individual rights and collective interests of consumers and users", for the assessment of responsibility and for the conviction of damages and refunds, deriving from damages or breaches, related to consumption. This trial institute, born in North America with the "mass tort litigation", is aimed to protect in the same process a multiplicity of subjective situations that are distinct but homogeneous. In the class actions, the claimant acts in the name of a group of individuals who have a right or common

\footnotetext{
${ }^{2}$ Martinello (2006) at 91.

${ }^{3}$ See, inter alia, Di Landro (2016) at 64 et seq.; Marcianò (2011) at 269 et seq.; Di Giacomo Russo (2012) at 170; Benatti, F. (2011) at 14 et seq.; Benatti (2012) at 5; Caporusso (2014) at 1199 et seq.

${ }^{4}$ BEUC, European Group Action. Ten Golden Rules, in http://www.beuc.eu/publications/2008 -00394-01-e.pdf.

${ }^{5}$ Ramello \& Porrini (2011) at 22.

${ }^{6}$ See App. Milan, Sec. II, 3 March 2014, in DeJure (Giuffrè legal database). In the same sense Tang (2011) at 101 et seq.; Martinello (2006) at 99.

${ }^{7}$ Marcianò (2011) at 271.

${ }^{8}$ Morani (2016) at 120 et seq.
} 
interest, i.e. a series of subjects holding positions suitable to be autonomously protected as for (contractual or extra contractual) damages compensation ${ }^{9}$.

Collective actions or class actions arise from the need to allow (for reasons of justice, procedural economy and legal certainty) those who are in a certain situation to benefit from the remedies that others, having acted in Court and having been victorious, may exercise against the defendant. Class actions allow to protect in a same judgment a multiplicity of subjective situations that are distinct (because they belong to different individuals), but homogeneous (because they originate from the same tort or infringement). The subjective situations object of protection through collective action derives from a mass damage: the plurality of prejudices caused by the same unlawful conduct.

The possibility of filing class action is aimed to recover economic loss (the redress of "non-economic" loss is a moot point ${ }^{10}$ ) by private individuals and, in the meantime, it produces a public goal - i.e. deterrence - that affects the correct functioning of market and social welfare ${ }^{11}$.

Moreover, class actions redress is to be placed along a deterrent/ sanctioning trend of contemporary tort law as referred to by the recent ruling in the field of punitive damages $^{12}$.

\section{European Background}

At European level, a system of "class action" has already been introduced through the Injunction directive (n. 98/27/CE), giving consumers associations a mandate to act on behalf of collective consumers interests.

Among EU initiatives which introduced forms of protection of the collective interests of consumers through actions of injunction, aimed at the cessation of professional harmful behaviour, we may recall the misleading advertising directive (1984), the abusive clause discipline (1993), the (above mentioned) directive concerning injunctions for the protection of consumers' rights and interests (1998) and lastly unfair commercial practices rules (2005).

Later, with the Recommendation 2013/396/EU (on common principles for injunctive and compensatory collective redress mechanisms in EU countries $)^{13}$, EU sets out a series of common (although not binding) principles for national collective redress mechanisms ${ }^{14}$.

The first aim is to enable citizens and companies to enforce their rights granted under European Union (EU) law, if they have been infringed. Furthermore, there is a need of justice, legal certainty and procedural economy. These redress mechanisms should be available in different areas where EU law grants rights, such as in consumer protection, competition, environmental

\footnotetext{
${ }^{9}$ Martinello (2006) at 91.

${ }^{10}$ Scognamiglio (2011) at 512; Afferni (2013) at 1275.

${ }^{11}$ Ramello \& Porrini (2011) at 22.

${ }^{12}$ Saguato (2018) at 17.

${ }^{13}$ Strong (2013) at 1 et seq.

${ }^{14}$ Panzani (2013) at 13 et seq. On the different perspectives of injunction and compensation in Italian law, see Pagni (2008) at 127 et seq.
} 
protection and financial services. In such cases the plaintiff does not pursue his/her own individual rights, but acts on behalf of consumer interests as such.

According to EU Recommendation 2013/396/EU collective redress procedures must be fair, equitable, timely and not prohibitively expensive. Collective redress systems should be based on the «opt-in» principle (see later paragraph 5) ${ }^{15}$. Under this principle, potential claimants who have not directly expressed their consent are not members of the group and therefore may not benefit directly from a favourable outcome of the collective redress proceedings.

However, although this decision is a perfectly legitimate exercise of public policy, its contraindications cannot be ignored: for example, the fact that «optin» procedures tend to result in smaller groups than «opt-out», thereby reducing the deterrent effect of the device ${ }^{16}$.

«Opt-in» choice with its smaller size is also the result of certain logistical difficulties associated with creating an «opt-out» class.

Developing the new cross-border class action, European institutions need to be aware of these sorts of pragmatic concerns and, if necessary, provide so that any procedures may reach the desired regulatory effect free from any distortion ${ }^{17}$.

In this perspective, according to EU policy, there should be procedural safeguards to avoid abuse of collective redress systems, such as: (i) the loser pays rule (the losing party is required to pay the winning party's legal costs); (ii) a ban on punitive (i.e. excessively high) damages; (iii) entities representing claimants should not be profit-making; (iv) a ban on the payment of contingency fees to lawyers.

As for (i), European system shares the loser pays rule in contrasts with the American rule, under which each party is generally responsible to pay its own attorneys' fees, unless a statute or contract provides for that assessment. The rationale for the English rule is that a litigant (whether bringing a claim or defending a claim) is entitled to legal representation and, if successful, should not be left out of pocket by reason of legal fees. This rule works where damages are considered as merely compensatory.

The ban of punitive damages (ii) - they are inflicted on the damage author with a satisfactory function and but the further purpose of preventing the repetition of the same behaviour that caused the harm (this ban was recently rejected by Italian Court of Cassation ${ }^{18}$ ) - in Europe aims to avoid that trial can be used as an opportunity for profit ${ }^{19}$ and for the same reason (iii) entities

\footnotetext{
${ }^{15}$ Strong (2013) at 64 et seq. This choice is due to many factors, for example to the fact that «opt-out» mechanism is not considered constitutionally correct in several European Member States.

${ }^{16}$ Strong (2013) at 66.

${ }^{17}$ Ibid.

${ }^{18}$ Recently, see Italian Court of Cassation (United Sections), 5 July 2017, n. 16601, in DeJure (Giuffrè, legal database), with comment of Ponzanelli (2017) at 1413 et seq.

19 The recent trend of the U.S. Supreme Court to limit exorbitant (reimbursements within) punitive damages, introducing more "realistic" amounts [BMW of North America Inc. v. Gore, 517 U.S. 559 (1996)], could at this point also turn our legislator - frightened by the disproportionate compensation granted by the American judges - back on its feet [Marcianò (2011) at 279].
} 
representing claimants should not be profit-making. This choice also reflects constitutional concerns expressed by various Member States, regarding the way in which punitive damages blend private and public (i.e., criminal law) goals. The decision to exclude punitive damages is incardinated in a public policy perspective. However, legal doctrines have suggested that it may reduce the regulatory value and the impact of class actions ${ }^{20}$. European authorities should rather consider whether the coherent European approach to cross-border class actions needs to adopt special devices to improve this regulatory effect and to counteract its reduction caused by the «opt-in» choice ${ }^{21}$.

Contingency fees to lawyers (iv) are in principle not admitted to avoid abuse of collective redress systems ${ }^{22}$.

The EU policies and principles are completely different from the American experience: here class actions are generally expensive, they involve high attorneys' fees, huge redress with punitive damages; they allow Courts to create public policy and overlap the legislative function of society regulation ${ }^{23}$.

According to Recommendation 2013/396/EU the judge has a key role in the collective litigation to effectively manage the case and also against any possible abuses. Claimants should be able to settle the case by means of collective consensual dispute resolution mechanisms (i.e. procedures whereby parties reach consensus on a solution).

Class actions therefore allow an effective protection of individual positions and at the same time perform a market regulation function through a more effective compensation; they are meant to the composition of the interests and conflicts that arise between market players ${ }^{24}$.

Class actions appear to be functional to the need of control and social responsibility of the enterprise ${ }^{25}$.

\section{Class Action Golden Anniversary}

Class action was firstly introduced in 1912 (radically modified in 1938) in the United States, but in 1966 it got its full implementation and actual physiognomy ${ }^{26}$ and thus, recently, the modern Rule 23 of Federal Rules of Civil

\footnotetext{
${ }^{20}$ Caporusso (2014) at 1199 et seq.

${ }^{21}$ Strong (2013) at 67.

${ }^{22}$ For an overview of punitive damages in U.S. system, see ex multis: Benatti (2008) at 231 et seq.

${ }^{23}$ However, these aspects are not necessarily related to class action litigation, but to the peculiarities of American system, that reflect political, ideological, constitutional, structural and technical differences between the systems that cannot be disregarded if one wants to approach the topic of class action suits from a comparative perspective; see Gidi (2003) at 315.

${ }^{24}$ In a market economy consumer satisfaction plays a central role. The possibility of solving conflicts quickly, cheaply and effectively has a great meaning, since group action can play an important role to strengthen the consumer side and to play a positive effect on the market as such; see Tang (2011).

${ }^{25}$ Martinello (2006) at 91.

${ }^{26}$ Moreover, it is useful to remember also the Class Action Fairness Act of 2005. See Frata (2006) at 13 et seq.; Poncibò (2006) at 124 et seq.
} 
Procedure had its golden anniversary ${ }^{27}$. The rule is rooted in the turbulent scenario of 1960s and was designed to enhance civil rights enforcement to challenge racial inequality and subordination ${ }^{28}$.

A half - century since its creation, in an incandescent American civil rights climate, Rule 23 rationale remains unchanged ${ }^{29}$, although also different purposes are at stake now: market regulation and incentives, private enforcement, efficiency and deterrence ${ }^{30}$. Nowadays, in fact, class action is useful to empower consumers to enter the regulatory framework by aligning public and private interests $^{31}$. Its power is to enable the vindication of claims (especially small claims), that otherwise would never be litigated; so, wide purposes had been involved since its birth: in addition to civil right, health and consumer protection, environmental matters, and so on ${ }^{32}$.

Now, it contains the model for class actions aimed to obtain compensation for damages deriving from the violation of parallel and homogeneous individual rights ${ }^{33}$. This model was fully followed in Quebec (since 1979) (34 $^{34}$ and in Australia (since 1991) ${ }^{35-36}$. We distinguish injunctive and damage class action.

The first is aimed to the cessation of the harm (inhibitory effect) and the correction of its effects, the second to damage compensation ${ }^{37}$.

The pillars of U.S. class actions are the aggregation of separate claims and the indirect representation of absent parties: through the class action, therefore, a limited number of members of the group constituted by those who have suffered the loss can propose a trial for the benefit of the whole group ${ }^{38}$.

\footnotetext{
${ }^{27}$ Malveaux (2018) at 325 et seq.: «The modern class action rule recently turned fifty years old - a golden anniversary. However, this milestone is marred by an increase in hate crimes, violence and discrimination. Ironically, the rule is marking its anniversary within a similarly tumultuous environment as its birth - the civil rights movement of the 1960's».

${ }^{28}$ In argument, see: Handler (1971) at 5 et seq.; Simon (1973) at 375 et seq.; Priest (1997) at 521 et seq.; Giussani (1996) at 155 et seq.

${ }^{29}$ Recently, see Malveaux (2018) at 325 et seq. Nowadays, according to the Author, prejudice against religious, ethnic and racial minorities, among others, and the rebirth of activism to counteract this trend lead back to the origin of the modern class action rule.

${ }^{30}$ Ramello \& Porrini (2011).

${ }^{31}$ Ramello \& Porrini (2011) at 2. For example, in the case of financial markets, according to law and economics perspective, this refers to investor's ability to file class action which are expost regulatory devices permitting the recovery of losses and generating a deterrent effect that promotes efficiency (at 4).

${ }^{32}$ Ramello \& Porrini (2011) at 9-10.

${ }^{33}$ Miller (2008) at 211 et seq.

${ }^{34}$ See Finn (2016).

${ }^{35}$ See Grave, Adams, Betts (2012).

${ }^{36}$ Class action litigation procedure, however, is not completely the same in different countries and in different States in U.S. The national laws differ as to the scope, the pre-requisites to take class action, the qualification of the acting party, the way to join claimants in the action and the binding effect over all claimants in the group action. In argument, see Tang (2011) at 101 et seq.

${ }^{37}$ Martinello (2006) at 92.

${ }^{38}$ Ramello \& Porrini (2011) at 11.
} 
Large powers are given to the judge, which concern both the admissibility of the class action ${ }^{39}$ and its conduct, also for the control of transactions between the parties, the calculation and distribution of compensation sums. If the class action is admitted, the judge establishes how to perform notification: i.e. how to inform all the potential interested parties about the start of the action. The notices must be made, if possible, through personal communication to the members of the group or, otherwise, through other forms of publicity decided by the judge, such as publication of advertisements in newspapers or even television messages.

A typical aspect of the U.S. class action is the «opt-out» system $^{40}$. Those entitled to "exclude themselves" from the action can express the «opt-out» right and proceed with individual actions. If consumer has not expressed the «opt-out» option the judgment will state against him ${ }^{41}$.

If the judge accepts the request, he may order the defendant to pay amounts in favour not only of the person who acted, but also of all those who are in a similar situation (although not individually identified at this stage). The total sum is paid to a special fund managed by administrative bodies under judicial supervision. It is possible that the unlawful gains of the defendant can sometimes be ascertained, but the victims of the crime are not detectable. In such cases, the Court can equally pronounce the sentence, and assign the relative sums to a group of subjects that corresponds approximately to the actual victims of the tort, with a mechanism called "fluid class recovery". In this case, the compensation for damages is attributed, rather than to the individuals who have suffered the offense, to the category of which they are part and the perpetrator of the crime is at least deterred from repeating it in the future ${ }^{42}$.

U.S. class action has increasingly been used to protect groups of citizens for damage to health or to the environment, to protect consumers for defective product damage and, more recently, investors and savers who are victims of financial loss. In the vast majority of cases, the class actions end with an agreement between the parties and not with a court order ${ }^{43}$.

Although originally envisioned as a device to protect consumers, class action litigation has become an inefficient mean of redress for individuals and a very costly eventuality for businesses ${ }^{44}$, with the problem of the overuse and the abuse of the litigation system. In fact, the number of class action proceedings in the United States is astonishing ${ }^{45}$; sometimes, the problem of over deterrence

\footnotetext{
${ }^{39}$ During the pre-trial phase, the judge must decide about the requirements of "numerosity", "commonality", "typicality" and "adequacy of representation". If these profiles occur, he admits class action (through "certification"). Otherwise, actors can decide to act individually. In argument, see: Marcianò (2011) at 278.

${ }^{40}$ Issacharoff (2002) at 1057 et seq.

${ }^{41}$ Those who, having received the notification, have not asked to be excluded from the group will be bound by the decision, which will produce the effects of res judicata against them.

${ }^{42}$ Martinello (2006) at 93.

${ }^{43}$ Martinello (2006) at 94; Marcianò (2011) at 279.

${ }^{44}$ Bondi (2010) at 615 et seq.

45 For further details, see Bondi (2010) at 607 et seq. For this reason, according to the Author, as for securities litigation, arbitration appears more efficient to resolve disputes minimizing the burdens of judicial systems.
} 
caused by so-called legalised black-mail lead the parties to compromise even in case of class actions of dubious validity ${ }^{46}$.

This situation determines a huge impediment to the competitiveness of U.S. businesses: nowadays, for instance, CEOs maintain that they prefer London to New York due to the litigation costs and risk associated with U.S. markets ${ }^{47}$.

\section{Italian Scenario of Class Action Litigation}

Currently, Draft law n. 1950 is being examined at Italian Senate with the aim to reform class actions rules. If this reform will pass, it will find a place in the new title VIII-bis, book IV, art. 840-bis to sexiesdecies, Civil Procedure Code (with the abrogation of art. 140-bis Cons. Code, now regulating class actions), creating a general redress right for mass damages (art. 840-bis c.p.c.) ${ }^{48}$ that matches with an injunction provision (art. 840-sexiesdecies c.p.c.) ${ }^{49}$.

At the moment, we find class action regulation in Italian Consumer Code ${ }^{50}$. Since its approval in the Italian system (with law 24 December 2007, n. 244), the discipline of class action has experienced a (difficult) regulatory and application process ${ }^{51}$, while in a few years the text of art. 140-bis Cons. Code has been reformed and modified in its framework.

Class action is a device through which each plaintiff, either an individual consumer or a consumer organization, can seek redress and ask for a decision on behalf of a group with equal or homogeneous rights, giving the members of the group the right to enforce their rights in accordance with the decision ${ }^{52}$. Claimants should be able to seek Court orders to cease violations of their rights granted by EU law ('injunctive relief': art. 140 Cons. Code) and to claim damages for harm caused by such violations ('compensatory relief': art. 140-bis Cons. Code) in a case where a large number of persons are harmed by the same unlawful practice.

The power to act through class action is given to any consumer or user, while the previous discipline enabled to act only consumer associations or committees considered by the judge adequately representative of collective interests.

Through this change (occurred in 2009), a clear distinction was made with respect to the collective inhibitory actions (articles 139 and 140 Cons. Code) that remain entrusted, not to individual representatives of a class, but to the representative associations of consumers included in the list provided for by art. 137.

Through the model of class actions of art. 140-bis (Azione di classe), the claimant aims to get an assessment of responsibility and a condemnation for

\footnotetext{
${ }^{46}$ See Agliassa (2012) at 83.

${ }^{47}$ McKinsey \& Co. (2007) at 75.

${ }^{48}$ See: http://www.senato.it/leg/17/BGT/Schede/FascicoloSchedeDDL/ebook/45728.pdf.

${ }^{49}$ For a comment to the bill, see Di Landro (2016) at 64 et seq.

${ }^{50}$ Alpa (2008) at 545 et seq.

${ }^{51}$ Caporusso (2014) at 1199 et seq.; Di Landro (2016) at 64 et seq.

52 Alpa (2010) at 379 et seq.; Panzani (2013). For a wide screen of Italian Courts judgments in this field see Afferni (2013) at 1275 et seq.; Ferrante (2017) at 64 et seq.
} 
damages compensation. According to art. 140-bis Cons. Code, the class action protects: a) the contractual rights of a plurality of consumers and users who are towards the same company in an homogeneous situation, including the rights related to contracts stipulated in accordance with articles 1341 and 1342 of the Civil Code; b) the homogeneous rights due to the final consumers of a given product towards the relative producer, even beyond the existence of a direct contractual relationship; c) the homogeneous rights to the redress of the prejudice deriving to the same consumers and users from unfair commercial practices or anticompetitive behaviour.

Not everyone can exercise a class action, but only consumers or users towards professionals ${ }^{53}$. According to art. 3 Cons. Code, consumer and user is "the natural person acting for purposes unrelated to business, commercial, craft or professional activity". Only "individuals" are considered consumers under the law ${ }^{54}$.

The plaintiff may give a mandate to a consumer association or committee to sue on his behalf. Each consumer can take a class action individually or through associations or committees in which he participates, according to the mechanism of legal representation (article 140-bis, paragraph 1, Cons. Code). The class action doesn't preclude individual protection, unlike the American system, which involves all the participants in the class with the different mechanism of the «opt-out», unless they expressly declare not wanting to get involved in the action.

Who can be sued? Only companies can be named as defendants under the law. Consumer code uses the word "impresa" to describe defendants. This word seems to include what is referred to as a "company" in English, the law does not specify the nature of the activity, nor is it precise about the necessity for the company to have its registered office on the national territory, or the possibility of having it even abroad. In the uncertainty left by the rule, it is deemed that both Italian and foreign companies may be sued by the new art. 140-bis Cons. Code ${ }^{55}$.

\footnotetext{
${ }^{53}$ See: App. Milan, 3 March 2014, in DeJure (Giuffrè legal database). In case of class action towards public administration we discuss of public class action which is regulated by Legislative Decree n. 198/2009. It is completely different from consumer class actions since it doesn't allow compensation but only injunction. In argument, see: T.A.R. Salerno (Campania), Sec. I, 16 October 2013, n. 2054, in DeJure (Giuffrè, legal database); Trib. Rome, 2 May 2013, ibid. In literature, see Marcianò (2011) at 275; Zingales (2012) at 1096 et seq. According to the Draft law n. 1950 (currently under discussion at Parliament), class action should be sued also towards public service or public utility body relating to events caused in carrying out their activities (art. 840-bis, par. 2, c.p.c.).

${ }^{54}$ This is a very controversial point for equality reasons: in particular, the impossibility to sue class actions for not-consumer subjects who may be in a situation of substantial awe and weakness compared to "strong" companies and may be holders of small claims (i.e. SME: small or medium enterprises), or for individuals who are in a similar situation, but are not consumer in a technical sense. For this reason, the Draft law n. 1950 (currently under discussion at Parliament) extends the active legitimacy to each component of the class (see art. 840-bis, par. 1, c.p.c.) without reserving it only to consumers. In argument, see Roppo (2010) at 24 et seq.

${ }^{55}$ Calcagno (2011) at 2.
} 
As for jurisdiction, the competent forum for class actions is the ordinary court of the capital city of the region where the defendant company has its registered office ${ }^{56}$.

Italian class action protects the homogeneous individual rights and collective interests of consumers and users.

Before the changes introduced by the decree of 2012 the second paragraph of the art. 140-bis specified that the various types of rights (protected with the class action) had to be "identical rights" 57 . The reference to the identity of the rights had the function of preventing that different situations could be deduced in the trial and with the expression "homogeneous rights", the legislator meant to refer to subjective legal situations characterised by the homogeneity of most of the constitutional elements ${ }^{58}$ (this criterion recalls the U.S. requirement of commonality) ${ }^{59}$.

Legal doctrine aimed to clarify this requirement has identified homogeneous individual rights as those interests of the single user or consumer (damages deriving from a defective product, from non-performance of a contract, from incorrect commercial practices) that share an analogous basis regarding multiple subjects ${ }^{60}$. Homogeneity is based on a common basis: the presence of a substantial assimilability of the various claims relative to the illicit conduct ${ }^{61}$.

Italian class action proceeding involves four main phases: (i) an admissibility decision, (ii) appeal, (iii) preliminary investigation (iv) a liability and damages stage $^{62}$.

${ }^{56}$ Draft law n. 1950 establishes that the class action has to be sued at the Tribunal, enterprise section (art. 840-ter, par. 1, c.p.c.).

${ }^{57}$ For the applications of this requirement, see e.g.: App. Turin, Sec. I, 23 January 2011, in Foro it., 2011, 3422, according to which the identity of the protected individual rights had not be understood according to an impracticable literal sense, but it would have been rather harmonised with the provision of homogeneity of these rights, contained in the first paragraph of art. 140-bis Cons. Code and then verified in relation to the petitum (to be understood as the object of protection and therefore of the required pronunciation: not the identity of any damage suffered by each investor, as mere unimportant circumstance, in the sense said, of the investors rights) and to the causa petendi (which legal reason for their foundation). See also: Trib. Rome, Sec. XIII civ., 11 April 201, in DeJure (Giuffrè, legal database), according to which for class action admissibility it was not enough to attach a damage that could be compensated (on the part of one or more consumers, so that collective action may be proposed), but the existence of a quid pluris represented by the general interest of the category or group, consisting in the identity of the rights due to consumers. To understand identity two conditions were required: a) whether they are rights that have the same origin, or arise from an identical constitutive fact; $b$ ) that these are rights whose assessment and protection involve the same matters of fact and law, so that the judge's decision can be based exclusively on assessments of a common nature that allow a uniform and unitary liquidation of damages for all potentially potential claims.

${ }^{58}$ Panzani (2013) at 5.

${ }^{59}$ See Caponi (2012) at 149; Panzani (2013) at 6; Winkler (2010) at 1675 et seq.

${ }^{60}$ See Calcagno (2011) at 2.

${ }^{61}$ Ibid.

62 The Draft law n. 1950 establishes three different steps in the class action proceeding: 1) certification, i.e. the assessment of class action admissibility, this phase ends with an ordinance with which (pursuant to art. 840-quinquies c.p.c.) the judge sets a deadline for the adhesion to the same action by subjects carrying homogeneous individual rights (art. 840-ter c.p.c.); 2) the decision that has a list of contents (among which, once again, the definition of "homogeneous 
At the end of the first hearing, the Court decides with ordinanza on the admissibility of the question (in the U.S. system this decision is the so-called certification $)^{63}$. This preliminary assessment of admissibility is not a mere "filter": on the one hand, its purpose is to protect (declaring inadmissibility) the defendant company against rash and pretentious actions that could jeopardise its professional image on the market, and, on the other hand, to incentivise (declaring admissibility) the adhesions of consumers holders of homogeneous rights, reassuring them of the officially of the initiative ${ }^{64}$.

The Court can suspend the judgment when on the same facts of the trial is underway an investigation before an independent authority or a judgment before the administrative judge. The judge cannot certify the action when it is manifestly unallowable, when there is a conflict of interest or when the judge sees no homogeneity of the individual rights that can be protected pursuant to art. 140-bis, par. 2, Cons. Code, as well as when the proponent does not appear able to adequately represent the interests of the class (art. 140-bis, par. 6, Cons. Code).

Art. 140-bis, par. 7, Cons. Code provides for the possibility to appeal against the order (ordinanza) that concludes the judgment of admissibility by presenting a claim before the Court of Appeal within the deadline of 30 days from its disclosure or notification if anterior ${ }^{65}$. The Court of Appeal pronounces the answer within 40 days from the filing of the appeal, with an order handed down in closed session. The appeal brought against the order does not suspend the proceedings before the Court.

individual rights", after which it is possible to proceed to the adhesions if not provided before); 3) third step, which includes: the possibility of further defence of the defendant on each application for membership; the decision of the delegated judge with a succinctly motivated decree on the acceptance, even partial, of the applications for membership; the preparation, by the common representative of the members, of a program indicating, for each member, the sums that the defendant will have to liquidate (art. 840-octies c.p.c.).

${ }^{63}$ De Cristofaro (2010) at 1932 et seq.; De Santis (2008) at 143 et seq.; Schirripa (2015) at 979 et seq.; Ferrante (2017) at 64 et seq. See for instance: Trib. Milan, 8 November 2013 in DeJure (Giuffrè legal database); Trib. Venice, Sec. III, 25 May 2017, ibid. For the requirement of homogeneity see: Trib. Venice, Sec. III, 12 January 2016, ibid; App. Venice, Sec. IV, 3 November 2017, n. 2696, ibid; App. Milan, 3 March 2014, ibid; App. Milan, Sec. II, 3 March 2014, ibid. According to this last ruling, for the correct interpretation of the term "homogeneous" (art. 140-bis Cons. Code), the rationale underlying the introduction of the class action must be taken into account. This rationale aims, on the one hand, to increase consumer confidence in the functioning of the market and in the use of an effective protection tool and, conversely, to allow entrepreneurs a general assessment of damages to be compensated, with a view to an overall simplification of consumer disputes. Therefore, it is not possible to claim that the legal position of a consumer must be completely overlapping with that of another, since this would result in a substantial repeal of the rule and would conflict with the legislative intent that used the adjective "homogeneous" in consistency with the purposes of the provision, since the cases must be similar but not identical.

${ }^{64}$ Amadei (2017) at 1856 et seq.; Fiorio (2012) at 377 et seq.; Conte (2010) at 100 et seq.

${ }^{65}$ Contrariwise, according to Draft law n. 1950, the judgment of the Court of Appeal can be appealed before the Court of Cassation (art. 840-ter, par. 7, c.p.c.). In jurisprudence, see: Cass., Sec. III, 24 April 2015, n. 8433, in DeJure (Giuffrè, legal database).Contrariwise, see: Cass., U.S., 1 February 2017, n. 2689, ibid.; see the comment of Amadei (2017) at 1856 et seq. 
The third stage is disciplined by paragraph 11: through the order of admissibility, the Court establishes the further course of the proceeding by "assuring, in respect of the contradictory trial, the fair, efficacious and prompt handling of the case". Together with this order (or rather with a later order which is adjustable or revocable at any time) the Court promulgates the preliminary inquiries as well as the provisions concerning the publicity that is to be done dropping any formality that is "not essential to the trial". In this phase, after the judge's order, the parties can present experts and the Court can name official technical Consultants, following the usual rules dictated by the Civil Procedure Code for the civil proceedings.

Italian system of class action is «opt-in» ${ }^{66}$ : according to art. 140-bis, par. 3, Cons. Code, consumers and users must adhere to the class action (without ministry of defence, even by certified e-mail and fax $)^{67}$.

The adhesion implies renunciation of any individual action based on the same title. Pursuant to paragraph 9, lett. b) of the art. 140-bis Cons. Code, the Court, with the ordinance of class action certification, establishes the peremptory term, not exceeding 120 days, within which the acts of adhesion, also through the plaintiff, are deposited in the chancellery. After the expiration of this deadline (for the adhesion) the possibility of proposing further class actions against the same company is excluded ${ }^{68}$. However, who has not joined in time can act individually to protect his/her rights.

Consumers ("aderenti") who decide to «opt-in» don't become technically parties in the proceedings; they will only share its results ${ }^{69}$. From a formal procedural point of view, the proceeding remains a bilateral one with only one party representing all the persons who «opted-in» ${ }^{70}$.

Once the criteria have been established to identify the class members (together with the forms, the terms for advertising the action and the deadline),

\footnotetext{
${ }^{66}$ Bruzzone \& Di Noia (2008) at 61 et seq.

${ }^{67}$ The formal act of adhesion to class action must contain all the personal data of the consumer and the documents proving his/her position with respect to the company. This act, in order to take effect, must be deposited, within the indicated deadline, at the judge's chancellery.

${ }^{68}$ According to Draft law n. 1950 (arts. 840-quinquies and sexies c.p.c.), each component can join the class action in two distinct moments: a) in the phase immediately following the ordinance that admits the action (and which sets a deadline for membership and defines the characteristics of homogeneous individual rights); b) in the phase following the sentence of conviction: while accepting the class action, the judge provides on the claims for compensation, but at the same time defines the characteristics of the homogeneous individual rights of the class, identifies the documentation to be produced by the members and assigns a term not exceeding 180 days for membership. In this stage, with the same provision, a delegated judge is also appointed to manage the membership procedure and a common representative of the members (art. 840-sexies c.p.c.). The common representative of the members is a new figure in class action proceeding: he has several powers, among which we can recall the preparation of the project of the homogeneous individual rights of the members, giving each one its justified conclusions and depositing it (art. 840-octies, par. 2, c.p.c.). The common representative of class members can ask the judge to appoint one or more experts with particular technical expertise to assist him in the assessment of the judicially relevant facts (art. 840-octies, par. 3, c.p.c.).

${ }^{69}$ Trib. Turin, 14 April 2014, in DeJure (Giuffrè legal database).

${ }^{70}$ Calcagno (2011) at 3.
} 
each consumer can join the class, the judge will fix the calendar of the process by deciding the date of the hearings and the manner in which they will have to perform the second stage of the trial. Thus, the trial continues with the hearings before the judge, who (in this second stage of the trial) has the task of ascertaining the facts to decide whether accepting or not the claim for damages in favour of all consumers who have joined the class. Considered the complexity of this proceeding, the legislator has given judge a wide discretionary power to manage the process in the best way and on a case-by-case basis.

Once the obstacle of certification is over, the campaign for membership by members of the class is ended, and the judge has performed the necessary investigations to verify the existence of the rights of consumers, there is the last stage of the trial with the pronunciation of the sentence of rejection/acceptance of consumers' claim.

If the claim is accepted, in addition to ascertaining the responsibility of the company, the judge will condemn the company to pay to each member adherent a sum of money ${ }^{71}$. This sum will be the same or different for each consumer: if the behaviour of the company has differently infringed the rights of consumers, in the sentence the judge will only indicate a homogeneous criterion of calculation that allows to go back to the sum due to each damaged. This prevents the judge from calculating for each damaged adherent the amount of damage suffered.

If consumers are not able to give proof of the precise amount of the damage suffered, the judge can establish it on an equitable basis ${ }^{72}$ : where the proof of the damage is impossible or difficult, the judge is given the chance to determine the amount in any case. This does not mean that the judge can condemn defendant to pay punitive damages that are, in principle, not consonant with our law order ${ }^{73}$.

Pursuant to paragraph 14, the sentence that defines the judgment applies to the members who took part in class action proceeding. According to paragraph 15 , the waivers and transactions between the parties do not affect the rights of members who have not expressly taken action.

All other consumers who have not participated to the class action litigation will be free to propose individual action, but not another class action based on the same facts.

What about non-pecuniary loss? From the point of view of the recent Courts trends ${ }^{74}$ and of Italian constitutional system - as well as of European private law - an exclusion of non-pecuniary damage (from the area of damages compensation with class action) would be a not justifiable choice in contradiction with what can be now defined as the esprit $d u$ temps on this field ${ }^{75}$; non-

\footnotetext{
${ }^{71}$ In argument, see Saguato (2018) at 15 et seq.

${ }^{72}$ Art. 140-bis, par. 12, Cons. Code.

${ }^{73}$ But, recently, see Cass., S.U., n. 16601/2017, cit., with comment of Ponzanelli (2017) at 1413 et seq.

${ }^{74}$ The benchmark for non-pecuniary losses in Italy is given by "San Martino rulings": Cass., U.S., 11 November 2008, n. 26972-26975, in Foro it., 2009, c. 139, with comment of Navarretta, Il valore della persona nei diritti inviolabili e la sostanza dei danni non patrimoniali.

${ }^{75}$ Scognamiglio (2011) at 512. According to Afferni (2013) at 1275 et seq., the two problems for the admissibility of non-pecuniary damage in class action proceedings are given by (i) the personalization of the damage and (ii) the requirement of the severity of the injury of an
} 
pecuniary loss should rather become the heart of the Italian class action so as to make it an efficacious and persuasive protection tool ${ }^{76}$.

In jurisprudence, the Court of Appeal of Milan has recently admitted the redress of non-pecuniary damages through the class action ${ }^{77}$.

The same decision was previously adopted by the Court of Appeal of Rome, where it is stated that in art. 140-bis Cons. Code there is no reason to infer the exclusion of claims for non-pecuniary damage, the existence of which is often linked to that of the pecuniary damage ${ }^{78}$.

On the contrary, according to Trib. Turin, the right to compensation for the non-pecuniary losses can't be considered an identical right from a causative perspective to different subjects ${ }^{79}$.

\section{«Opt-in»v. «opt-out» Procedure}

The difference between «opt-in» and «opt-out» procedure is that in the first, consumers have to declare that they intend to join the trial ${ }^{80}$, in «opt-out» all consumers (who suffered the damage) are automatically considered as belonging to the group, unless they explicitly express the «opt-out» right declaring that they do not want to participate. With «opt-out» options consumers will not suffer the (negative or positive) effects of the final verdict ${ }^{81}$.

It is not very easy to affirm which is the more efficient system; maybe a European class action system should admit both an «opt-out» and an «opt-in» procedure. It should be up to the Court to decide, case by case and on the basis of objective criteria, which approach is best suited ${ }^{82}$.

Of course, the «opt-out» system may offer a better protection to consumers especially when they are unaware that their rights have been infringed or when they couldn't declare to join the procedure. The «opt-in» system carries with it the risk of not protecting those consumers who wanted to take part in the trial, but (for instance) have not been informed.

However, according to the European tradition, the «opt-out» class action proceeding is somehow unfair for absent class members. Binding those who do not consent to participate in the litigation and preventing them from pursuing another action elsewhere may be considered as depriving these individuals of their access to justice ${ }^{83}$.

\footnotetext{
inviolable right; thus, he maintains that the first principle avoids different injuries to be sued trough the same class actions, while the second principle should be dismissed or at least tempered in the class action.

${ }^{76}$ Calcagno (2011) at 6.

77 App. Milan, 25 August 2017 (in Nuova Giurisprudenza Civile Commentata, 2018, n. 1, with comment of Saguato, Azione di classe e risarcimento del danno non patrimoniale “omogeneo").

${ }^{78}$ App. Rome, 27 January 2012, in DeJure (Giuffrè, legal database).

79 Trib. Turin, ord., 31 October 2011, ibid.

${ }^{80}$ Gidi (2003) at 337 et seq.

${ }^{81}$ Leskinen (2010) at 1 et seq.

${ }^{82}$ Such criteria could be for example the nature of the claim, its value, and the number of potential claimants.

${ }^{83}$ Tang (2011) at 101 et seq.
} 
«Opt-out» may sometimes be more difficult to combine with national (civil law) procedural principles ${ }^{84}$ : we consider, for instance, art. 81 (Italian Civil Procedure Code) in the light of which «outside the cases expressly provided for by the law, no one can assert in his own name a right of others»; as well as art. 2909 (Italian Civil Code) that provides: «the assessment contained in the final sentence has effects between the parties, their heirs or assignees» (not therefore with reference to third parties, however identified or identifiable on the basis of their membership to the same group or to the same class).

Parties seeking to assert multinational class actions may experience significant problems as a result of U.S. courts' standard use of «opt-out» mechanisms, since some countries view «opt-out» procedures as constitutionally suspect and will not enforce a judgment if a plaintiff did not affirmatively opt into the lawsuit ${ }^{85}$.

In any cases, information has crucial importance: it is necessary that specific and appropriate measures are taken to reach and inform consumers. Victims can't get their redress if they don't know that class action is taking place and if they can't take the necessary steps to include or exclude themselves from the group of claimants. In an «opt-in» procedure, the consumers who are victims of the illegal practices need to know of the trial in order to join if they wish.

In the «opt-out» case, consumers may want to exclude themselves from the group in order to bring individual actions or because they don't want to claim compensation, in both case they need to know that such action has been initiated ${ }^{86}$.

\section{Comparative Outlines}

Although class action has long been typical of American system, it is a newer and growing litigation device also in many other countries ${ }^{87}$.

In Europe, United Kingdom is the historical homeland of class actions introduced by law in 1998 and then modified in 2000 by Conditional Fee Agreement Regulation concerning group litigation (GLO: Group litigation order): it disciplines a legal instrument that allows the Court, even ex officio, to issue an order ("group litigation order") that identifies, in the presence of common or connected matters of law and a significant number of potential disputes, the "litigation group", which must be submitted to the knowledge of a single judge ("management court") and a "group register" in which all disputes concerning the group will be registered ${ }^{88}$.

\footnotetext{
${ }^{84}$ Gidi (2003) at 344 et seq.

${ }^{85}$ Strong (2012) at 18.

${ }^{86}$ BEUC, European Group Action. Ten Golden Rules, in http://www.beuc.eu/publications/ 2008-00394-01-e.pdf.

${ }^{87}$ However, compared to the Common Law countries, collective redress in Europe is at an "experimental" stage: see Tang (2011) at 101 et seq. For a study of class actions in a comparative perspective see: Fairgrieve \& Howells (2009) at 379 et seq.

${ }^{88}$ Marcianò (2011) at 279 et seq.
} 
The system requires that the lawyer can apply a basic hourly rate with a surcharge in the case of a positive outcome ("success fee") and no fee in the case of losing. In the event of a negative outcome of the action, there is a specific insurance policy that relieves the plaintiffs from paying the opponent's litigation costs and the lawyer's rate ${ }^{89}$.

While the Supreme Court of the United States was arguably making class actions more difficult to pursue ${ }^{90}$ (as reflected in its Spokeo, Inc. v. Robins ruling, explaining, in a putative class action, that a showing of concrete and particularised injury is required to establish standing), Europe several system have introduced some sort of group action in their legislation, referred to as group action, multiparty action or collection action ${ }^{91}$.

In Sweden, for instance, in 2003 a Group Proceedings Act entered into force introducing a class action proceeding (which allows consumers class actions, actions by organizations and class actions tout court) equivalent to U.S. class action; there are special conditions but no certification procedure; the Swedish government chose the «opt-in» model instead of «opt-out» ${ }^{92}$.

Also in France class actions are well-known: the Loi de santé (26 January 2016), which went into effect on July 1, 2016, permits class action litigation in France within the healthcare and cosmetic product industries. The Loi de modernization du système de santé is not France's first legal occasion for class actions. Antitrust and consumer class action litigation has been available in France since the Consumer Act (the Loi Hamon of 17 March 2014) which went into effect on October 1, 2014. French action de groupe belongs to «opt-in» system, according to which it is up to consumers to express their consent to be included in the group and, at the same time, to renounce individual action ${ }^{93}$.

As for Germany, the Civil Procedure Code does not contemplate mass litigation. Special class/collective actions are included in the Act on Cease and Desist Actions of 2001 (which provides for collective actions resulting from alleged infringements of certain consumer rights); the Unfair Competition Act of 2005; the Act against Restraints of Competition, enacted in 1958 and afterwards reformed (which provides for collective actions resulting from alleged unfair competition, and commercial anti-competitive behaviour); the Capital Markets Model Proceedings Act of 2006 (which provides for a collective action for allegedly incorrect, misleading or missing capital markets information); the

\footnotetext{
${ }^{89}$ The incentive for lawyers and the insurance prevision have a double effect. On the one hand, they allow access to justice even to those who otherwise could not risk a negative outcome of the dispute; on the other hand, they guarantee a careful choice of actions in terms of the merits of the claims as, if a action is not well founded, no insurance company will be willing to guarantee the payment of litigation costs (if not with high premiums that nobody will be willing to take on) just as no lawyer will bear the risk (uninsured) of not receiving fees: see Marcianò (2011) at 280.

${ }^{90}$ Benatti (2012), at 10 et seq.; Benatti (2015) at 675 et seq.; Benatti (2014) at 500 et seq.

${ }^{91}$ Marcianò (2011) at 279 et seq.

${ }^{92}$ Marcianò (2011) at 282.

${ }^{93}$ Torino (2010) at 330.
} 
Appraisal Proceedings Act of 2003 (which provides for compensation claims for minority shareholders following corporate organization measures) ${ }^{94}$.

In Spain, the Ley de Enjuiciamiento of 7 January 2000 contains protection of consumers and users, as shown in art. 1, which distinguishes collective actions, depending on the possibility of identifying individual members of the class ${ }^{95}$.

Another example of the collective action is the one of the Dutch Act on the Collective Settlement of Mass Damage claims, which entered into force from July 27, 2005. This Act permits competent representing associations to enter into a settlement agreement with the liable company on behalf of all the affected persons. The representing associations and the liable party could then apply to the Court of Appeal of Amsterdam to declare the settlement agreement binding on all interested persons who did not choose to $\left\langle\right.$ opt-out ${ }^{96}$.

If we have to consider also a not-European experience, we may look at the Brazilian scenario where class action has been considered a model also for civil law countries, since it demonstrates that civil law systems can employ a class suit procedure successfully but cannot transplant the American class action model into their systems without substantial adaptation ${ }^{97}$. The peculiarity of this model is that only a public organ can act through class action and, in case of consumers, only consumers' committee and associations. It is a public-private system for the protection of collective rights: through ação colectiva which reflect the ancient roman action popularis ${ }^{98}$. Adapting to the civil-law tradition and the peculiarities of local culture and needs, the Brazilian class action legislation of consumer code is seen as a unique regulation which joins class law suits, types of group rights, res judicata, lis pendens and several other important aspects $^{99}$.

\section{Class Actions at the Test Bench}

If we have to draw conclusion as for the application of class action rules in Italy, we may affirm that there are only few cases and most of them don't exceed the stage of certification ${ }^{100}$.

Italian (class actions) case law concerns conflicts due to (by way of example): travel and transport contracts, bank contracts, tobacco damages, computer software, public service provisions, road maintenance, pharmaceutical/ healthcare products and services, unfair commercial practices: all these litigations are related to consumer issues.

At the moment, class action is an instrument that concerns not all kind of rights, but only consumer rights ${ }^{101}$. The fundamental rights are therefore excluded

\footnotetext{
${ }_{95}^{94}$ For German experience, see: Torino (2010) at 332; Marcianò (2011) at 280.

95 Torino (2010) at 331 et seq.

96 Torino (2010) at 330.

${ }^{97}$ Gidi (2003) at 311 et seq.

${ }^{98}$ D'orta (2014) at 257.

${ }^{99}$ Gidi (2003) at 311 et seq.; D'orta (2014) at 257.

${ }^{100}$ Caporusso (2014) at 1199 et seq.; Afferni (2013) at 1275 et seq.; Ferrante (2017) at 64 et seq.

${ }^{101}$ In a critical sense, see Roppo (2010) at 24 et seq.; Libertini \& Maugeri (2010) at 882 et seq.
} 
(as well as other important issues: such as environmental matters and securities litigation not related to consumers) from the scope of class action, although according to legal doctrine the largest challenge of our age and the degree of democracy of a country are measured on the effectiveness of the protection of these rights; indeed, even historically, this sector appears to be the most significant in U.S. experience as for class action litigation ${ }^{102}$.

Moreover, the actual regulatory framework presents some other leaks: if it is a public policy to prevent market failures, the system cannot fail to protect professionals - in the B2b and B2Customer relations - or (similarly) "weak" bodies. The overcoming of the (subjective) consumer perspective towards an (objective) protective dimension - i.e. protection of the "weak party" tout court - appears more useful for the strengthening of the effectiveness of the class actions. The modern legal doctrine currently talks about the protection of "customers" (rather than consumers only) within unbalanced business relationships, thus underlining the existence of disadvantaged situations (not belonging to consumers area) worthy of protection for the purpose of the correct functioning of the market ${ }^{103}$.

It is a common view that the regulation of the unbalanced contracts should not be limited to consumer's contracts. The asymmetry of contractual power between the strong and the weak contractor is, in principle, structural, regardless of whether the contractor acts as a consumer or as a trader. In the presence of unequal bargaining power, the asymmetry between the parties is intrinsic to the process regardless of the (possible) professional activity of the weak contractor.

If we consider the rationale of consumer law (i.e. the removal of the physiological asymmetries between the contracting parties), we must consistently admit that the problem of their applicability arises with regard to of any contractor, regardless of whether he is a consumer or a professional ${ }^{104}$.

In this perspective, a step forward is made by Draft law n. 1950 which does not limit class action litigation only to consumers' issues but allows it to all component of a certain class without any subjective specificity ${ }^{105}$.

Thus, the changes that are envisaged in the (aforementioned) bill, currently under discussion in Italian Parliament, may give to the class action the necessary impulse to make it a more effective device not only for consumers, but also to all those who are victims of a mass damage. Analysing the bill, we can see, among the others: the extension of active legitimacy, the introduction of incentives for actors and representatives, guarantees in the overall performance procedure and a more detailed regulation of the entire procedure ${ }^{106}$.

By a European perspective, we should consider the opportunity of an introduction of mechanism which covers both national and cross-border cases since victims of the same professional are scattered throughout several EU

\footnotetext{
${ }^{102}$ Alpa (2010) at 8.

${ }^{103}$ Roppo (2009) at 267 et seq.; Chiarella (2016) at 110 et seq.

${ }^{104}$ Ibid.

${ }^{105}$ Art. 840-bis c.p.c.

${ }^{106}$ Schirripa (2015) at 979 et seq.
} 
Member States ${ }^{107}$. Until now, only some EU consumers can benefit from efficient collective lawsuit; for its part, EU does not provide expressly for a special law and forum in the technical sense. In cross-border cases, only a European class action would finally place all EU citizens on an equal footing by allowing consumers from different European countries who have suffered the same damage to join together to ask compensation. A class action at European level is necessary for justice and legal certainty i.e. to avoid having different results in EU countries for the same damage.

Once decided positively about the opportunity of a European collective class action, what about jurisdiction? Three seems to be the solutions.

According to a first option: it's not necessary to revise the current jurisdiction rules but it is helpful to integrate them by inserting a specific article into the regulation concerning collective redress.

Contrariwise, a second option maintains that the Brussels I Regulation should introduce an innovative provision permitting collective redress to be brought either in the Courts of the Member State where the defendant has his domicile, or in the Courts of the Member State with which the action as a whole has the closest connection (the closest connection should be decided by taking into consideration the number of consumers domiciled within the country, the number of contracts related to the country, and the damages arising out of the contracts relating to this country). According to a third option, the Brussels I Regulation should introduce new provisions on collective actions to be sued in the Courts of the Member State which is the domicile of any consumer, providing the defendant has pursued his commercial activities in, or directed his commercial activities to, that country ${ }^{108}$.

These three options should be evaluated by considering the socio-economic impact of collective suit as a whole. Observation should be taken from the perspective both of consumers and of businesses as for access to justice, businesses' expectations, fair trading, market functioning, efficiency and costs. The third option basically permits pan-European collective redress being brought in any consumer's domicile, but it is impractical since it would generate great uncertainty and litigation risk on the part of businesses ${ }^{109}$.

The first option is the less trenchant, since it requires only clarifying the current jurisdictional rules for class actions. It can be useful, as it can provide certainty in terms of interpretation and application of the current rules applied in collective redress practice. Furthermore, it is a "precautionary" approach at the "experimental" stage of European cross-border collective redress. This approach could be easily accepted by businesses and industries at the moment ${ }^{110}$. Even the second option is a practicable choice because it conciliates both the defendant's reasonable expectation and consumers' access to justice.

\footnotetext{
${ }^{107}$ BEUC, European Group Action. Ten Golden Rules, in http://www.beuc.eu/publications/ 2008-00394-01-e.pdf.

${ }^{108}$ For the three options, see: Tang (2011) at 101 et seq.

${ }^{109}$ Ibid.

${ }^{110}$ Idib.
} 


\section{Concluding Remarks}

The recent judgment of European Court of Justice in the case Maximilian Schrems v. Facebook Ireland Limited shows that there is the need of a European regulation of class action, since (at the moment and according to ECJ) consumers who bring legal proceedings against professionals in cross-border conflicts lose their status of consumers ${ }^{111}$. Pursuant to this last ruling, the user is in principle a "consumer" if he acts individually against the social network and not together with other users ${ }^{112}$.

In the case examined by the Court of Justice, Schrems accuses Facebook of violating various data protection provisions regarding its private Facebook account and the accounts of other users who gave him their rights to the action.

Facebook, for its part, believes that the Austrian Courts are not competent, that Schrems cannot be considered a consumer, because he uses Facebook also for professional purposes, and he cannot be protected by EU law that allows consumers to sue professionals before the Courts of their own place of residence

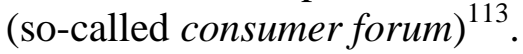

This specific protection (consumer forum - Reg. 1215/2012) in the access to justice works when consumers sue a corporation for breach of contract (they can file their claims directly in their member State of residence, irrespective of other jurisdictional links of the dispute $)^{114}$. Problems arise when the consumer decides to take class actions. According to the recent ruling of the European Court of Justice, the consumer forum cannot be invoked in proceedings brought by a consumer (in the Court of the place where he is domiciled) with a view to asserting (not only his own claims but) also claims assigned by other consumers domiciled in the same Member State, in other Member States or in non-member countries $^{115}$.

As for the status of consumer, in fact, the Court affirms that the consumer forum, in principle, applies only in the case where the purpose of the contract

\footnotetext{
${ }^{111}$ For the background of this ruling, see: Morani (2016) at 120 et seq.

${ }^{112}$ ECJ, 25 January 2018, C-498/16.

113 In the contrary, general jurisdiction regime is based on the defendant's domicile. The rationale of consumers' protective jurisdiction is to protect them from a disadvantaged litigating and bargaining situation. In argument, see case C-89/91Shearson v TVB [1993] ECR I-139, para 18: «[T]he special system established ... is inspired by the concern to protect the consumer as the party deemed to be economically weaker and less experienced in legal matters than the other party to the contract, and the consumer must not therefore be discouraged from suing by being compelled to bring his action before the courts in the Contracting State in which the other party to the contract is domiciled».

${ }^{114}$ Consumer forum is incompatible with cross-border conflicts, where consumers may come from different Member States and, thus, special jurisdiction rules are needed for the "collective redress": it is necessary to see whether any of the existing jurisdiction provisions can be properly applicable to a collective action. See Tang (2011) at 101 et seq.

${ }^{115}$ According to the Court, consumer forum was established in order to protect the consumer as a party to the contract: a consumer is therefore protected only in so far as he is, in his personal capacity, the applicant or defendant in proceedings. Consequently, an applicant who is not himself a party to the consumer contract in question cannot enjoy the benefit of the jurisdiction relating to consumer contracts. The same also applies in regard to a consumer to whom the claims of other consumers have been assigned.
} 
concluded between the parties concerns a non-professional purpose. With regard to the services of a digital social network which tend to be used over a long period, it is necessary to take into account the further development of the use made of these services.

According to the Court, the complex activity of organizing and leading such lawsuit might acquire the traits of an entrepreneurial activity, in contrast with the status of a consumer.

With this judgment, the ECJ meant not to overlap the legislative function of society regulation, creating ex novo the requirements of a European class action and thus not intervening in public policy decisions.

Somehow, the same situation occurred when the Court was called to delimitate the horizon of consumer protection: in that case the Court didn't evade its institutional borders by assuming (cryptically) that law definitions are of legislator's competence ${ }^{116}$.

Now, we have to draw some conclusions. Globalization has led to an everincreasing number of large-scale legal conflicts that have cross-border relevance ${ }^{117}$, but, at this moment, international class actions face many difficulties in Europe because little attention is paid to the cross-border effect of consumer collective redress ${ }^{118}$ and because of the pitfalls generated by transnational regulatory litigation ${ }^{119}$.

In this perspective, it would be useful to remove class action regulation from national law, attributing it exclusively to the EU bodies. Indeed, the adoption of a harmonised European mass litigation would guarantee certain advantages in terms of enlargement of supply and strengthening of the competition: factors which may create a benefit effect to the market on the whole (also for the reduction of prices, due to the increase of cross-border trade and relations) ${ }^{120}$.

Another brake for class action proceedings is given by costs that the plaintiff is called to bear and that have a certain dissuasive effect to take class action. The principle loser pays exposes the plaintiff, in case of negative outcome of the dispute, to afford legal expenses incurred by the defendant; while in the previous phase, in the event of a preliminary assessment of inadmissibility, the plaintiff may be exposed to the additional expense of advertising the eventual

\footnotetext{
${ }^{116}$ ECJ, 22 November 2001, proceedings C-541/99 e C-542/99, in Giur. it., 2002, 543 with comment of Fiorio, Professionista e consumatore, un discrimine formalista?; ECJ, 14 March 1991, C-361/89, in curia.eu and ECJ, 19 January 1993, C-89/91, ibid.

117 Strong (2012) at 14: considered the amount of trade between the U. S. and the European Union, conflicts involving U.S. and European parties may be among the most frequent to happen. Moreover, mass disputes are becoming increasingly common at an inter-European level, with a 2008 survey estimating that ten percent of the collective redress cases involving the ten - thirteen Member States with collective redress mechanisms was cross- border in nature (Directorate General for Internal Policies, Overview of Existing Collective Redress Schemes in EU Member States - July 2011, available at http://www.europarl.europa.eu/docu ment/activities/cont/201107/20110715ATT24242/20110715ATT24242EN.pdf at 43).

${ }^{118}$ In most Member States, collective redress litigation is in fact primarily limited to domestic claims.

${ }^{119}$ Tang (2011) at 101 et seq.; Strong (2012) at 76.

${ }^{120}$ Agliassa (2011) at 185.
} 
negative ordinance. For this reason, the Draft law n. 1950, currently under discussion, introduces (same, but small) cost reductions for plaintiff, with economic incentives for lawyers. In this perspective, for example, the bill provides that "when a technical consultant is appointed, the obligation to pay the expenses, the advance payment and the compensation due shall be paid by the defendant" (art. 840-quinquies) ${ }^{121}$. While art. 840-novies c.p.c. introduces a reward for the common representative of the members and lawyers.

These cues are particularly interesting, although maybe not fully satisfactory from a "system" point of view: we have to bear in mind the case law that has denied the existence of the requirement of adequacy to consumers without adequate financial and organizational resources ${ }^{122}$ : if class action fulfils the purpose of allowing the collective exercise of those actions that could not be proposed by individuals as excessively expensive, it is contrary to the same spirit of the law to consider admissible only those actions proposed by the wealthy consumers (able to bear the costs for collective actions that are undoubtedly far superior to the individual ones) ${ }^{123}$.

Thus, in conclusion, the lack of a European regulation ${ }^{124}$, the inexistence of a trans-national coordination, the high costs and the circumstance that (where class actions exist) the «opt-in» system is often widespread are all factors that risk making this instrument idle and ineffective in practice ${ }^{125}$.

\section{References}

Afferni, G. (2013). 'Recenti sviluppi nell'azione di classe', in Contratto e impresa 6: 1275-1292.

Agliassa, L. (2012). La class action nei confronti delle banche. In http://www.dirit tobancario.it/sites/default/files/allegati/agliassa_l._la_class_action_nei_confronti_ delle_banche_2013.pdf.

Alpa, G. (2010). 'L'art. 140-bis del codice del Consumo nella prospettiva del diritto privato', in Conte G. \& Vigoriti V. (Eds.), Futuro, Giustizia, Azione collettiva, Mediazione. Turin: Giappichelli.

Alpa, G. (2008). 'L'azione collettiva risarcitoria. Alcune osservazioni di diritto sostanziale', in I Contratti 6: 545-553.

Amadei, D. (2017). 'Azione di classe - L'azione di classe inammissibile, tra effetti preclusivi e ricorso per Cassazione', in Giurisprudenza italiana 8-9: 1856-1864.

Benatti, F. (2008). 'Danni punitivi e "class actions" nel diritto nordamericano', in Analisi giuridica dell'economia 1: 231-243.

Benatti, F. (2011). 'Il danno nell'azione di classe'. Danno e responsabilità 1: 14-21.

\footnotetext{
${ }^{121}$ Di Landro (2016) at 64 et seq.

122 Trib. Turin, ord. 28 aprile 2011; Trib. Turino, ord. 7 aprile 2011, with comment of Fiorio, Solo il consumatore ricco può curare adeguatamente gli interessi della classe? La legittimazione ad agire alla luce delle prime esperienze applicative dell'art. 140-bis, in Giurisprudenza di merito, 2012, 2, 377.

${ }^{123}$ Fiorio (2012) at 377 et seq.

${ }^{124}$ At this moment, U.S. class action seems to face the same problems in cross-border conflicts: see Benatti (2012), at 10 et seq.

${ }^{125}$ Morani (2016) at 120 et seq.
} 
Benatti, F. (2014). 'La fuga verso l'arbitrato: la crisi (ir)reversibile della class action statunitense', in Rassegna di diritto civile 2: 500-517.

Benatti, F. (2015). 'La giustizia statunitense alla prova dei Mass Torts: il caso In re Deepwater Horizon', in Responsabilità civile e previdenza 2 2: 675-687.

Benatti, F. (2012). 'Note in tema di class actions trasfontaliere', in Danno e responsabilità 1: 5-11.

Bondi, B. J. (2010). 'Facilitating Economic Recovery and Sustainable Growth through Reform of the Securities Class-Action System: Exploring Arbitration as an Alternative to Litigation', in Harvard Journal of Law and Public Policy 33: 607638. Available at SSRN: https://ssrn.com/abstract=1601305.

Bruzzone, G. \& Di Noia, C. (2008). 'Il sistema di “opt-in” italiano', in Analisi giuridica dell'economia 1: 51-63.

Caponi, R. (2012). 'Azioni di classe: il punto, la linea e la discontinuità', in Foro italiano 4: $149-154$.

Calcagno, N. (2011). 'Italian class action: the beginning'. Available at SSRN: http://ssrn. com/abstract $=1875424$.

Caporusso, S. (2014). 'L'azione di classe nel diritto vivente: un laboratorio in itinere', in Rivista di diritto civile 5: 1199-1219.

Chiarella, M.L. (2016). Contrattazione asimmetrica. Segmenti normativi e costruzione unitaria. Milan: Giuffrè.

Conte, G. (2010). 'Dalla tutela collettiva in senso proprio alla tutela cumulativa: l'azione di classe a protezione dei diritti dei consumatori e degli utenti', in Conte G. \& Vigoriti V. (Eds.), Futuro, Giustizia, Azione collettiva, Mediazione. Turin: Giappichelli.

De Cristofaro, M. (2010). 'L'azione collettiva risarcitoria "di classe": profili sistematici e processuali', in Responsabilità civile e previdenza 10: 1932-1948.

De Santis, F. (2008). "La pronunzia sull'ammissibilità della "class action": una “certification" all'italiana?', in Analisi giuridica dell'economia 1: 143-165.

Di Giacomo Russo, B. (2012). 'La class action italiana', in Il giudice di pace 2: 169176.

Di Landro, A.C. (2016). 'La "nuova" azione di classe. Linee di riforma e riflessioni critiche', in I contratti 2: 64-71.

D'orta, C. (2010). La class actions tra proclami e deterrence. Uno studio di diritto interno e comparato. Turin: Giappichelli.

Fairgrieve, D. \& Howells G. (2009). 'Collective redress procedures-European debates', in International and Comparative Law Quarterly 58: 379-409.

Ferrante, E. (2017). 'Azione di classe - la via italiana alla class action fra interesse di classe e regole ostruzionistiche per le adesioni', in Giurisprudenza italiana 1: 6471.

Finn, S. (2016), The Quebec class actions: a roadmap, Toronto: LexisNexis.

Fiorio, P. (2002). 'Professionista e consumatore, un discrimine formalista?', in Giurisprudenza italiana 3: 543-546.

Fiorio, P. (2012). 'Solo il consumatore ricco può curare adeguatamente gli interessi della classe? La legittimazione ad agire alla luce delle prime esperienze applicative dell'art. 140-bis', in Giurisprudenza di merito 2: 367-390.

Gidi, A. (2003). 'Class Actions in Brazil - A Model for Civil Law Countries', in The American Journal of Comparative Law 51: 311-408. Available at SSRN: https:// ssrn.com/abstract $=903188$.

Giussani, A. (1996). Studi sulle "class actions". Padova: Cedam.

Grave, D., Adams, K., Betts, J. (2012). Class actions in Australia. Pyrmont, N.S.W.: Thomson Reuters (Professional). 
Handler, M. (1971). 'The shift from substantive to procedural innovations in antitrust suits: the twentythird annual antitrust review', in 71 Colum. Law Rev. 1: 1-36.

Hodges, C. (2010). 'Collective Redress in Europe: The New Model', in Oxford Legal Studies Research Paper 24: 1-27. Available at SSRN: https://papers.ssrn.com/ sol3/papers.cfm?abstract_id $=1551985$.

Issacharoff, S. (2002). 'Preclusion, Due Process, and the Right to Opt Out of Class Actions', in Notre Dame Law Review 77: 1057-1082; in Columbia Law School, Pub. Law Research Paper 02-40. Available at SSRN: https://ssrn.com/abstract= 306001 or http://dx.doi.org/10.2139/ssrn.306001.

Leskinen, C. (2010). 'Collective Antitrust Damages Actions in the EU: The Opt-In v. The Opt-Out Model', in IE Law School Working Paper 10-03: 1-56. Available at SSRN: https://ssrn.com/abstract=1612731 or http://dx.doi.org/10.2139/ssrn.1612731.

Libertini, M. \& Maugeri, M. (2010). 'Il giudizio di ammissibilità dell'azione di classe, nota a Trib. Torino, ord. 27 maggio 2010', in Nuova giurisprudenza civile commentata 1: 882-889.

Malveaux, S.M. (2018). 'The Modern Class Action Rule: Its Civil Rights Roots and Relevance Today', in CUA Columbus School of Law Legal Studies Research Paper 2018-2: 325-396. Available at SSRN: https://ssrn.com/abstract=3103020.

Marcianò, A. (2011). 'Azione collettiva: diverse esperienze a confronto', in Il lavoro nella giurisprudenza 3: 269-282.

Martinello, P. (2006). 'La Class Action', in Consumatori, Diritti, Mercato 1: 90-117.

McKinsey \& Co. (2007). Sustaining New York's and the U.S. Global Financial Services Leadership. Available at http://www.nyc.gov/html/om/pdf/ny_report_fi nal.pdf.

Miller, G.P. (2008). 'Punti cardine in tema di "class actions" negli Stati Uniti e in Italia', in Analisi giuridica dell'economia 1: 211-230.

Morani, M. (2016). 'L'azione di classe in Europa, aspettando la Corte di Giustizia europea sul caso Schrems v. Facebook', in Int'l Lis 3-4: 120-128.

Pagni, I. (2008). 'Azione inibitoria delle associazioni e azione di classe risarcitoria: le forme di tutela del codice del consumo tra illecito e danno', in Analisi giuridica dell'economia 1: 127-142.

Panzani, L. (2013). 'La class action nel diritto italiano e nel diritto europeo'. www.dis tretto.torino.giustizia.it/distretto/allegato_corsi.aspx?File_id_allegato=1301.

Ponzanelli, G. (2017). 'Le Sezioni Unite sui danni punitivi tra diritto internazionale privato e diritto interno', in Nuova Giurisprudenza Civile Commentata 10: 14131415.

Priest, G.L. (1997). 'Procedural Versus Substantive Controls of Mass Tort Class Actions', in 26 Journal Legal Studies S2: 521-573.

Ramello, G. B. \& Porrini, D. (2011). 'Class Action and Financial Markets: Insights from Law and Economics', in Journal of Financial Economic Policy 3(2): 140160. Available at SSRN: https://ssrn.com/abstract=1742371.

Roppo, V. (2009). 'Prospettive del diritto contrattuale europeo. Dal contratto del consumatore al contratto asimmetrico?', in Corriere giuridico 2, 267-282.

Roppo, V. (2010). 'Regolazione del mercato e interessi di riferimento: dalla protezione del consumatore alla protezione del cliente?', in Rivista di diritto privato 3: 19-35.

Saguato, F. (2018). 'Azione di classe e risarcimento del danno non patrimoniale "omogeneo", in Nuova Giurisprudenza Civile Commentata 1: 15-21.

Schirripa, M. (2015). 'Azione di classe e ordinanza di inammissibilità - Il Commento', in I Contratti 11: 979-985.

Scognamiglio, C. (2011). 'Risarcimento del danno, restituzioni e rimedi nell'azione di classe', in Responsabilità civile e previdenza 11: 501-522. 
Simon, W. (1973). 'Class actions: useful tool or engine of destruction', in Federal Rules Decisions 55: 377-386.

Strong, S.I. (2013). 'Regulatory Litigation in the European Union: Does the U.S. Class Action Have a New Analogue?', in Notre Dame Law Review 88: 899-971; in University of Missouri School of Law Legal Studies Research Paper No. 2012-25. Available at SSRN: https://ssrn.com/abstract=2123608.

Torino, R. (2010). 'Dalla 'azione collettiva risarcitoria' alla 'azione di classe'. Un'analisi comparatistica', in Alpa G., Conte G., Di Gregorio V., Fusaro A., Perfetti U. (Eds.), Il diritto dei consumi. Aspetti e problemi, Naples: Edizioni Scientifiche Italiane, pp. 325-353.

Tang, Z.S. (2011). 'Consumer Collective Redress in European Private International law', in Journal of Private International law 7: 101-141.

Winkler, M. (2010). 'L'azione di classe italiana: problemi teorici e applicativi di una normativa difficile', in Responsabilità civile e previdenza 7-8: 1675-1696.

Zingales, M. (2012). 'La class action pubblica e i suoi limiti nelle ipotesi di disfunzioni organizzative: una sentenza monito', in Giornale di diritto amministrativo 11: 1096-1103. 
